\title{
ANALISIS MASA SIMPAN PRODUK SAMBAL TEMPOYAK BERPOTENSI SEBAGAI PRODUK OLEH-OLEH BARU
}

\author{
Dini Junita ${ }^{1}$, Maryam Novitasari ${ }^{2}$ \\ ${ }^{1,2}$ Prodi Ilmu Gizi STIKes Baiturrahim Jambi \\ Email.dinijunita.dj.dj@gmail.com
}

\begin{abstract}
Tempoyak is one of traditional food from Jambi Province. The innovation product of tempoyak that commonly consumption in community is Sambal Tempoyak. The processing of tempoyak into sambal is intended to improve the taste, but the shelf life is short. Vacuum packaging is expected to be able to maintain the quality of Sambal Tempoyak. This quantitative experimental research is analyzed descriptively to draw conclusions. Tempoyak used in this research comes from traditional markets in the Jambi city. Sambal tempoyak made with herbs and spices adding. After cooked and cooled, the sambal tempoyak was packed with plastic and vacuumed using a vacuum sealer. The products storage in two temperatures; room temperature and cold temperatures and then, test of levels of microbial contamination using the Total Plate Count test. Test starting from the first day of processing ( 0 days of storage), $7^{\text {th }}$ day, $14^{\text {th }}$ day, and $21^{\text {th }}$ day. The results showed the number of sambal tempoyak microbes stored at room temperature lower than sambal tempoyak which is stored in the refrigerator temperature and storage age of the product until the 21st day after processing, but Klabsiella Ozaenae contamination occurred in the 14th day sample. Further research, suggested to examine the bacteria that contaminate this product so the prevention about this bacterial can applied by hazard analysis critical control point.
\end{abstract}

Keywords : Klabsiella Sp., Shelf Life, Tempoyak, Total Plate Count, Traditional Food

\begin{abstract}
ABSTRAK
Tempoyak adalah salah satu makanan tradisional dari Provinsi Jambi. Produk inovasi tempoyak yang biasa dikonsumsi masyarakat adalah Sambal Tempoyak. Pengolahan tempoyak menjadi sambal dimaksudkan untuk meningkatkan rasanya, tetapi umur simpannya pendek. Kemasan vakum diharapkan mampu menjaga kualitas Sambal Tempoyak. Penelitian eksperimental kuantitatif ini dianalisis secara deskriptif untuk menarik kesimpulan. Tempoyak yang digunakan dalam penelitian ini berasal dari pasar tradisional di kota Jambi. Sambal tempoyak dibuat dengan bumbu dan rempah-rempah. Setelah dimasak dan didinginkan, sambal tempoyak dikemas dengan plastik dan disedot menggunakan vacuum sealer. Penyimpanan produk dalam dua suhu; suhu kamar dan suhu dingin, uji kadar kontaminasi mikroba menggunakan uji bilangan kuman. Tes total mmikroba dimulai dari hari pertama pengolahan (0 hari penyimpanan), kemudian hari ke 7, hari ke 14, dan hari ke 21. Hasil penelitian menunjukkan jumlah mikroba sambal tempoyak yang disimpan pada suhu kamar lebih rendah dari sambal tempoyak yang disimpan dalam suhu lemari es dan usia penyimpanan produk sampai hari ke-21 setelah pengolahan. Namun terjadi kontaminasi Klabsiella Ozaenae pada sampel hari ke-14. Penelitian selanjutnya, kami sarankan untuk mempelajari sumber bakteri ini sehingga pencegahan dapat diterapkan melalui proses Hazard Analyze Critical Control Point.
\end{abstract}


Kata kunci : Bilangan Kuman, Klabsiella Sp., Makanan Tradisional, Masa Simpan, Tempoyak

\section{PENDAHULUAN}

Tempoyak merupakan produk olahan dari fermentasi spontan buah durian yang melibatkan bakteri asam laktat dengan penambahan garam. Tempoyak biasa dimanfaatkan sebagai bumbu masak oleh masyarakat di daerah penghasil durian seperti Lampung, Jambi, Sumatera Selatan, Bengkulu, Kalimantan Barat, Sumatera Barat, dan Aceh. Secara definisi, nama tempoyak diserap dari teknik pengolahannya yaitu dari kata poyak sehingga dapat dikatakan nama tempoyak didapatkan karena cara pengolahan durian yaitu mengoyak (Rahman 2017 dalam Haruminori 2017).

Proses fermentasi menjadikan tempoyak memiliki bau yang kuat dan rasa yang khas. Manfaat lain dari proses fermentasi ini adalah peningkatan nilai cerna bahan pangan, menurunkan kandungan antigizi atau bahan lain yang tidak dikehendaki, dan dapat menghasilkan produk atau senyawa turunan yang bermanfaat bagi manusia. Namun laju fermentasi yang terus berlangsung menghasilkan alkohol dan $\mathrm{CO}_{2}$ sehingga menyebabkan penurunan mutu tempoyak akibatnya daya simpan menjadi singkat.

Pengolahan tempoyak penting dilakukan karena dapat memperpanjang umur simpan, meningkatkan nilai jual, dan menambah nilai gizi. Salah satu inovasi pengolahan tempoyak adalah sambal tempoyak. Menurut Utami (2012) sambal adalah saus dari bahan dasar cabe yang menyerupai bubur dan biasanya ditambah bahan-bahan lain seperti garam, bawang merah dan bawang putih. Sambal memiliki cita rasa bervariasi menurut tingkat kepedasannya.

Saat ini produk olahan tempoyak dalam kemasan belum banyak terdapat di pasaran, sehingga potensial untuk dilakukan. Pengolahan tempoyak menjadi sambal tempoyak dan pengemasan vakum diharapkan mampu menjaga mutu sambal tempoyak. Pengemasan vakum merupakan alternatif yang baik, karena dapat menyebabkan laju respirasi oleh bakteri menurun, mengurangi pertumbuhan mikroba, mengurangi kerusakan oleh enzim, memberikan efek visual yang baik bagi produk, dan memperpanjang umur simpan produk.

Manfaat dari pengolahan tempoyak ini salah satunya adalah pelestarian makanan khas daerah dan menciptakan peluang usaha. Menurut Wirawati (2002), bahwa fermentasi asam laktat pada prinsipnya dapat meningkatkan kandungan asam amino esensial. Sifat awet yang ditunjukkan oleh tempoyak baik untuk kesehatan, karena pengawetan yang terjadi tidak menggunakan bahan kimia yang akhir-akhir ini dihindari oleh konsumen karena dikahwatirkan dapat menimbulkan efek karsinogenik.

Bahan makanan dapat
mengalami kerusakan yang
disebabkan oleh mikroorganisme,
pH, suhu, enzim, oksigen, dan waktu
(Muchtadi,2013). Untuk itu perlu
diteliti bagaimana perkembangan
mikroba selama penyimpanan


sambal tempoyak kemasan sehingga dapat dilakukan estimasi masa simpannya.

\section{METODE PENELITIAN}

Penelitian ini telah dilakukan pada bulan Juli-Agustus 2018, pembuatan produk sambal tempoyak dilakukan di laboratorium pengolahan makanan gizi dan pangan Sekolah Tinggi Ilmu Kesehatan Baiturrahim Jambi dan pengujian total plate count dilakukan di Laboratorium Kesehatan Provinsi Jambi.

Jenis penelitian ini adalah eksperimental dengan menggunakan uji total plate count dilakukan sebelum penyimpanan sambal tempoyak (0 hari) dan setelah penyimpanan sambal tempoyak pada hari ke7, 14, dan 21.

Rancangan percobaan ini menggunakan Rancangan Acak Lengkap (RAL) dengan dua faktor. Faktor yang pertama adalah suhu penyimpanan meliputi suhu ruang $\left(28-32^{\circ} \mathrm{C}\right)$ dan suhu refrigerator (2$\left.8^{\circ} \mathrm{C}\right)$. Sedangkan Faktor yang kedua adalah waktu penyimpanan yakni 7 hari, 14 hari dan 21 hari. Dengan variable yang dilihat adalah total mikroba. Data penelitian kuantitatif yang telah dikumpulkan dan diperhitungkan dengan bilangan kuman kemudian dianalisis secara deskriptif

\section{HASIL DAN PEMBAHASAN}

Setiap bahan makanan secara alami memiliki mikroorganisme yang hidup pada bahan makanan tersebut. Mikro- organisme dalam bahan makanan ini memiliki beberapa peranan salah satunya ialah dapat membantu proses fermentasi dan beberapa jenis mikroorganisme dapat menyebabkan kerusakan makanan sehingga menurunkan mutu makanan tersebut.

Total plate count atau angka lempeng total adalah metode untuk menghitung angka cemaran bakteri dengan media natrium agar pada suatu sampel bahan makanan tanpa mengelompokan jenis-jenis bakteri tertentu. Sambal tempoyak yang telah disimpan selama 7 hari, 14 hari dan 21 hari masing-masing di uji jumlah cemaran bakterinya. Hasil pengujian total plate count atau bilangan kuman sambal tempoyak dapat dilihat pada tabel 1 .

Menurut Affandi (2011)

Fermentasi adalah proses penguraian substrat oleh aktivitas mikroorganisme yang dapat berlangsung secara aerob atau anaerob. Fermentasi sambal tempoyak terjadi secara spontan atau alami tanpa penambahan inokulum atau kultur murni. Fermentasi tempoyak ini terus berlanjut meski tempoyak telah diolah menjadi sambal tempoyak dan telah dikemas secara vakum karena beberapa bakteri alami pada tempoyak masih hidup dan melakukan metabolisme sel untuk menghasilkan energi. 
Tabel 1 Hasil Bilangan Kuman Sambal Tempoyak

\begin{tabular}{|c|c|c|c|c|c|}
\hline \multirow[b]{2}{*}{ No } & \multirow[b]{2}{*}{ Masa simpan } & \multicolumn{2}{|c|}{ Nilai } & \multirow[b]{2}{*}{$\begin{array}{l}\text { Standar } \\
\text { Normal }\end{array}$} & \multirow[b]{2}{*}{ Keterangan } \\
\hline & & Suhu Ruang & $\begin{array}{l}\text { Suhu } \\
\text { Refrigerator }\end{array}$ & & \\
\hline 1 & Hari ke-0 & \multicolumn{2}{|c|}{$467 \mathrm{Cfu} / \mathrm{gr}$} & & Dapat dikonsumsi \\
\hline 2 & Hari ke-7 & $10 \mathrm{Cfu} / \mathrm{gr}$ & $120 \mathrm{Cfu} / \mathrm{gr}$ & & Dapat dikonsumsi \\
\hline 3 & Hari ke-14 & 13.500 & 750.000 & & Tidak Dapat \\
\hline & & $\mathrm{Cfu} / \mathrm{gr}$ & Cfu/gr & $1 \times 10^{4} \mathrm{Cfu} / \mathrm{gr}$ & dikonsumsi \\
\hline 4 & Hari ke-21 & $70 \mathrm{Cfu} / \mathrm{gr}$ & $80 \mathrm{Cfu} / \mathrm{gr}$ & (BPOM) & Dapat dikonsumsi \\
\hline
\end{tabular}

Pengolahan sambal tempoyak yang rendah karena baru mulai
ini menggunakan proses pemanasan menyesuaikan diri. Pada fase sebelum sambal tempoyak dikemas selanjutnya yaitu fase pertumbuhan vakum dan disimpan. Pemanasan ini bakteri membelah dengan cepat dan bertujuan untuk memasak atau konstan mengikuti kurva logaritmik. mematangkan sambal tempoyak Pada fase ini kecepatan pertumbuhan sehingga sambal tempoyak tidak sangat dipengaruhi oleh medium cepat basi dan pemanasan ini dapat tempat tumbuhnya seperti $\mathrm{pH}$, menyebabkan bakteri-bakteri tertentu kandungan nutrien, suhu dan mati.

Pertumbuhan Bakteri adalah pertambahan volume dan ukuran sel dan juga sebagai pertambahan jumlah sel. Pertumbuhan sel bakteri biasanya mengikuti suatu pola pertumbuhan tertentu berupa kurva pertumbuhan sigmoid. Pertumbuhan bakteri memiliki 4 fase yaitu Fase adaptasi, fase pertumbuhan, fase statis, dan fase kematian. Kurva pertumbuhan bakteri dapat dilihat pada gambar 1.

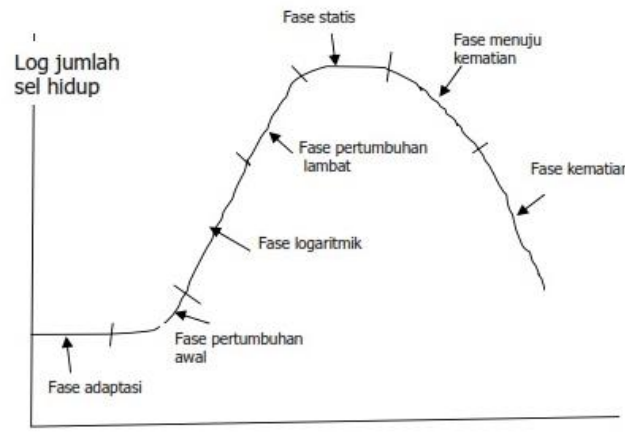

waktu

Gambar 1. Kurva pertumbuhan Bakteri

Pada fase adaptasi, bakteri mulai membelah dengan kecepatan kelembaban udara. Pada fase ini mikroba membutuhkan energi lebih banyak daripada fase lainnya. Pada fase ini kultur paling sensitif terhadap keadaan lingkungan. Peneliti berpendapat bahwa meningkatnya kadar karbohidrat pada sampel sambal tempoyak penyimpanan 7-14 hari disebabkan karena bakteri pada tempoyak berada pada fase pertumbuhan ini sehingga semakin banyak jumlah bakteri maka penguraian karbohidrat kompleks menjadi gula sederhana meningkat.

Pada akhir fase pertumbuhan jumlah populasi bakteri masih naik karena jumlah sel yang tumbuh masih lebih banyak dari pada jumlah sel yang mati hal ini disebabkan oleh nutrisi didalam medium berkurang dan adanya hasil-hasil metabolisme yang mungkin beracun atau dapat menghambat pertumbuhan mikroba. Pada fase statis jumlah populasi bakteri tetap karena jumlah sel yang tumbuh sama dengan jumlah sel yang mati namun ukuran sel pada fase ini menjadi lebih kecil karena sel tetap membelah meskipun zat-zat 
nutrisi sudah habis. Kekurangan nutrisi ini memungkinkan sel bakteri mempunyai komposisi yang berbeda dengan sel bakteri yang tumbuh pada fase logaritmik. Pada fase statis selsel bakteri lebih tahan terhadap keadaan ekstrim seperti panas, dingin, radiasi maupun bahan-bahan kimia. Fase kematian bakteri ini disebabkan oleh nutrisi dalam medium yang telah habis dan energi cadangan dalam sel yang telah habis. Kecepatan kematian bakteri tergantung dari kondisi nutrien, lingkungan dan jenis bakteri.

Hasil isolasi bakteri pada tempoyak yang dominan adalah kelompok bakteri asam laktat genus Lactobacillus dengan spesies $L$. plantarum, L. Casei,dan $L$. Fermentum (Reli, 2016). Sedangkan hasil penelitian Hasanuddin (2010) yang telah mengidentifikasi mikroflora pada tempoyak diketahui bahwa ada enam spesies bakteri yang tumbuh pada tempoyak yaitu Pediococus acidilactici, $L$. plantarum, L. curvatus, Leuconostoc mesentroides, S. saprophyticus dan Micrococcus varians. Dari keenam spesies tersebut empat spesies yang berperanan positif pada fermentasi tempoyak yaitu $P$. acidilactici, $L$. plantarum, L. curvatus dan Leu. mesentroides. Dua spesies yang merugikan adalah Staphylococcus saprophyticus dan Micrococcus varians. Sedangkan dari identifikasi bakteri sambal tempoyak peneliti menemukan jenis bakteri yang berbeda yaitu Klabsiella Ozaenae.

Menurut Darmayasa (2008) golongan bakteri Klabsiella sp.mampu mendegradasi lipid atau lemak. Menurut Ernawati (2010) bakteri dengan genus Basillus dapat memfermentasi gula jenis glukosa, laktosa, dan maltosa. Bakteri Klabsiella Ozaenae merupakan bakteri gram negatif berbentuk batang. Namun, belum diketahui asal bakteri Klabsiella Ozaenae yang mengkontaminasi produk sambal tempoyak ini. Klebsiella sp. merupakan jenis bakteri Enterobactericeae yang memang lebih dominan berada di traktus gastrointestinal orang dewasa. Namun demikian, anak bayi dan balita menjadi lebih rentan terinfeksi jika kondisi kesehatan dan gizinya buruk. Penelitian Hatmaningtyas (2013) menemukan bahwa tidak terdapat hubungan yang bermakna antara lokasi tempat tinggal dan higienitas air dengan kolonisasi Klebsiella sp. Serta bakteri ini tidak ditularkan melalui udara melainkan melalui kontak dengan tangan yang terkontaminasi Klebsiella sp. ataupun kontaminasi dari lingkungan.

\section{SIMPULAN}

Berdasarkan hasil penelitian ini dapat disimpulkan sebagai berikut :

1. Gambaran jumlah mikroba pada produk sambal tempoyak selama penyimpanan pada suhu ruang yaitu jumlah mikroba bertambah sejalan lama hari penyimpanan dan masih dalam batas aman dikonsumsi. Namun sampel sambal tempoyak penyimpanan hari ke 14 pada suhu ruang diduga terkontaminasi pada saat pengujian total plate count sehingga hasil angka cemaran bakteri melebihi standar BPOM dan tidak dapat dikonsumsi.

2. Gambaran jumlah mikroba pada produk sambal tempoyak selama 
penyimpanan pada suhu dingin (refrigerator) yaitu jumlah mikroba bertambah seiring lama hari penyimpanan dan masih dalam batas aman dikonsumsi. Namun sampel sambal tempoyak penyimpanan hari ke 14 pada suhu ruang diduga terkontaminasi pada saat pengujian total plate count sehingga hasil angka cemaran bakteri melebihi standar BPOM dan tidak dapat dikonsumsi.

3. Gambaran hubungan suhu dengan masa simpan dilihat berdasarkan jumlah total bakteri yaitu suhu ruang memiliki kandungan jumlah mikroba lebih sedikit dibandingkan yang disimpan pada refrigerator.

4. Perkiraan masa simpan produk sambal tempoyak pada penelitian ini adalah 21 hari

\section{SARAN}

Masih terdapat kekurangan dari penelitian ini, yaitu penyimpanan hari ke- 22 hingga ke -29 tidak dilakukan pengujian, sedangkan pada hari ke -30 produk tempoyak sudah memiliki kandungan mikroba melebihi batas aman. Sehingga tidak diketahui pada hari ke berapa setelah hari ke-21 produk ini tidak dapat dikonsumsi. Bagi peneliti selanjutnya dapat meneliti sumber bakteri yang mengkontaminasi pada produk ini sehingga dapat diterapkan pencegahan masuknya bakteri sebagai prosedur Hazard Analysis Critical Control Point.

\section{DAFTAR PUSTAKA}

1. Affandi, Erwin dan Yuniati, Heru. (2011). Pemanfaatan Limbah Ampas Kelapa Sawit Sebagai Substrat Untuk Sintesis Zat Gizi Melalui Fermentasi Kapang Rhizopus Oligosporus. Jurnal Penelitian Gizi dan Makanan Vol.34(2):123-130.

2. Darmayasa, IBG. (2008). Isolasi Dan Identifikasi Bakteri Pendegradasi Lipid (Lemak) Pada Beberapa Tempat Pembuangan Limbah Dan Estuari Dam Denpasar. Jurnal Bumi Lestari Vol. 8(2).122-127

3. Fellows, P. J. (2009). Food Processing Technology : Principles and Practice, Edisi 3. Yohanus, Penerjemah. (2012). Teknologi Pengolahan Pangan : Prinsip dan Praktik. EGC. Jakarta

4. Haruminori, Amanda. dkk. (2017). Makanan Etnik Melayu: Tempoyak. Jurnal Antropologi: Isu-Isu Sosial Budaya Vol. 19 (2): 125-128.

5. Hasanudin. (2010). Mikroflora Pada Tempoyak. Jurnal AGRITECH Vol. 30(4).

6. Hatmaningtyas. (2013). Faktor Risiko Kolonisasi Klebsiella Sp. Pada Nasofaring Balita. Jurnal media medika muda. Fakultas Kedokteran Universitas Diponegoro : Semarang.

7. Julianto, Tatang S. dan Hidayat, Habibi. (2018). Pedoman Praktikum Biokimia. Universitas Islam Indonesia: Yogyakarta. 
8. Lestari, Lily A. dkk. (2018). Dasar-dasar Mikrobiologi Makanan di Bidang Gizi dan Kesehatan. Gadjah Mada University Press: Yogyakarta.

9. Muchtadi, Tien R. dan Sugiono. (2013). Prinsip dan Proses Teknologi Pangan. Alfabeta: Bandung.

10. Nurmalinda, Azizah. dkk. (2013). Isolasi Dan Karakterisasi Parsial Bakteri Indigenous Pemfermentasi Dari Buah Durian (Durio Zibethinus Murr.) Jurnal Biologi Universitas Andalas Vol 2(1) : 8-13.

11. Rachmawati, Rani dkk. (2009). Pengaruh Suhu Dan Lama Penyimpanan Terhadap Kandungan Vitamin C Pada Cabai Rawit Putih (Capsicum frustescens). Jurnal Biologi Vol. 13 (2) : 36-40

12. Reddy, G. (2008). Amylolytic bacterial lactic acidfermentation-A review. Biotechnology Advances Vol.26(1): 22-34.

13. Reli, Rapeka. (2016). Modifikasi Pengolahan Durian Fermentasi (Tempoyak) Dan Perbaikan Kemasan Untuk Mempertahankan Mutu Dan Memperpanjang Umur Simpan. Skripsi. Bogor: Institut Pertanian Bogor.

14. Renate, Dharia. dkk. (2014). Model Kinetika Degradasi Capsaicin Cabai Merah Giling Pada Berbagai Kondisi Suhu Penyimpanan. Jurnal Agritech Vol. 34(3)

15. Safaryani, Nurhayati dkk. (2007). Pengaruh Suhu dan
Lama Penyimpanan terhadap Penurunan Kadar Vitamin C Brokoli (Brassica oleracea L). Jurnal Buletin Anatomi dan Fisiologi Vol. 15(2).

16. Sandjaja, Budiman. dkk. (2010). Kamus Gizi. Kompas: Jakarta.

17. Shewfelt, Robert L. (2009). Introducing Food Science. Haryanto. Natalia, Penerjemah. (2011). Pengantar Ilmu Pangan. EGC. Jakarta.

18. Sucipto, Cecep D. (2016). Keamanan Pangan untuk Kesehatan Manusia. Gosyen Publishing: Yogyakarta.

19. Sumantri, Abdul Rohman. (2013). Analisis Makanan. Gadjah mada university press: Yogyakarta.

20. Suprihatin. (2010). Teknologi Perpindahan Massa Dalam Perancangan Proses Reaksi. UNESSA press : Surabaya.

21. Syahputra, A. (2015). Variasi penambahan sukrosa terhadap mutu cocoghurt menggunakan Enterococcus faecalis UP-11 isolated dari Tempoyak. J Faperta. 2(1).

22. Thaib, Novita. (2015). Isolasi Capsaicin Dari Oleoresin Cabai Rawit (Capsicum Frutescens L.). Jurnal Chem. Prog. Vol.8(2).

23. Utami, Dian Ayu. (2012). Studi Pengolahan Dan Lama Penyimpanan Sambal Ulek Berbahan Dasar Cabe Merah, Cabe Keriting Dan Cabe Rawit Yang Difermentasi. Skripsi. Makasar: Universitas Hasanudin. 
24. Widawati, L. Dan Nur'aini, H. (2015). Quality Analysis of "Sambal Tempoyak" with Variation Additions of Salt, Types of Chili and StabilizerI. Dalam : International Seminar on Promoting Local Resources for Food and Health. Bengkulu. 12-13 Oktober 2015.

25. Widawati, Lina. Efrianti, Susi. (2015). Preferensi Panelis dan Efektifitas Penggunaan Bahan Penstabil Terhadap Mutu Sambal Hijau Tempoyak. Jurnal Aplikasi Teknologi Pangan Vol 4(1).

26. Yenrina, Rina. (2015). Metode Analisis Bahan Pangan dan Komponen Bioaktif. Andalas university press: Padang.

27. Yuliana, Neti. (2007). Perubahan Karakteristik Biokimia Fermentasi Tempoyak Menggunakan Pediococcus Acidilactici Pada Tiga Tingkat Konsentrasi Gula. Jurnal AGRITECH Vol. 27(2). 